\title{
Article \\ Effect of Selenium Nanoparticles on Germination of Hordéum Vulgáre Barley Seeds
}

\author{
Shahida Anusha Siddiqui ${ }^{1,2, * \mathbb{C}}$, Andrey Vladimirovich Blinov ${ }^{3}$, Alexander Vladimirovich Serov ${ }^{3}$, Alexey \\ Alekseevich Gvozdenko ${ }^{3}$, Alexander Aleksandrovich Kravtsov ${ }^{3,4}{ }^{3}$, Andrey Ashotovich Nagdalian $3, *(0)$, \\ Vladislav Viktorovich Raffa ${ }^{3}$, David Guramievich Maglakelidze ${ }^{3}{ }^{(0)}$, Anastasiya Alexandrovna Blinova ${ }^{3}$, \\ Anna Vitalievna Kobina ${ }^{3}$, Alexey Borisovich Golik ${ }^{3}$ iD and Salam A. Ibrahim ${ }^{5, *(\mathbb{D})}$
}

Citation: Siddiqui, S.A.; Blinov, A.V.; Serov, A.V.; Gvozdenko, A.A.; Kravtsov, A.A.; Nagdalian, A.A.; Raffa, V.V.; Maglakelidze, D.G.; Blinova, A.A.; Kobina, A.V.; et al. Effect of Selenium Nanoparticles on Germination of Hordéum Vulgáre Barley Seeds. Coatings 2021, 11, 862 https://doi.org/10.3390/ coatings 11070862

Academic Editor: Jean-François Berret

Received: 16 June 2021

Accepted: 14 July 2021

Published: 19 July 2021

Publisher's Note: MDPI stays neutral with regard to jurisdictional claims in published maps and institutional affiliations.

Copyright: (c) 2021 by the authors. Licensee MDPI, Basel, Switzerland. This article is an open access article distributed under the terms and conditions of the Creative Commons Attribution (CC BY) license (https:/ / creativecommons.org/licenses/by/ $4.0 /)$.
1 Technical University of Munich Campus Straubing for Biotechnology and Sustainability, Essigberg 3, 94315 Straubing, Germany

2 DIL e.V.-German Institute of Food Technologies, Prof.-von-Klitzing-Straße 7, 49610 Quakenbrück, Germany

3 Department of Physics and Technology of Nanostructures and Materials, North-Caucasus Federal University, Pushkina Street 1, 355009 Stavropol, Russia; ablinov@ncfu.ru (A.V.B.); sav_ncstu@mail.ru (A.V.S.); gvozdenko.1999a@gmail.com (A.A.G.); sanya-kravtsov@ya.ru (A.A.K.); vladunchik200126@gmail.com (V.V.R.); ogoniock2015@mail.ru (D.G.M.); nastya_bogdanova_88@mail.ru (A.A.B.); zmejka-2007@mail.ru (A.V.K.); lexgooldman@gmail.com (A.B.G.)

4 Laboratory of Physics and Technology of Semiconductor Nanoheterostructures for Microwave Electronics and Photonics, Federal Research Center, The Southern Scientific Centre of the Russian Academy of Sciences, Chehova Street 41, 344006 Rostov-on-Don, Russia

5 Food Microbiology and Biotechnology Laboratory, North Carolina Agricultural and Technical State University, E. Market Street 1601, Greensboro, NC 24711, USA

* Correspondence: shahidasiddiqui777@gmail.com or S.Siddiqui@dil-ev.de (S.A.S.); geniando@yandex.ru (A.A.N.); ibrah001@ncat.edu (S.A.I.)

Abstract: Within the framework of this study, the effect of nanoparticles of the essential trace element selenium stabilized by Polyvinylpirrolidone (PVP) C15 (8 $\pm 2 \mathrm{kDa})$ and ascorbic acid on the germination of barley seeds has been studied. Selenium nanoparticles stabilized by PVP C15 $(8 \pm 2 \mathrm{kDa})$ and ascorbic acid, characterized by a spherical shape, monodisperse size distribution, and a diameter of about $70 \pm 5 \mathrm{~nm}$, were obtained by the chemical reduction method. The experiment compared the effect of selenium nanoparticles and selenous acid on seed germination. The positive effect of preparation of selenium nanoparticles stabilized by PVP C15 (8 $\pm 2 \mathrm{kDa})$ and ascorbic acid on the length of roots and shoots, the number of roots, and the percentage of seed germination has been revealed. It was determined that the highest percentage of Hordeum vulgare L. culture seed germination was achieved using a preparation of selenium nanoparticles stabilized by PVP C15 $(8 \pm 2 \mathrm{kDa})$ and ascorbic acid at a concentration of of $4.65 \mu \mathrm{g} / \mathrm{mL}$. Analysis of the results showed that selenium in the form of nanoparticles has an order of magnitude that is less toxic than in the form of selenous acid. The study of morphological and functional parameters during the germination of Hordeum vulgare L. seeds allowed us to conclude that selenium nanoparticles can be successfully used in agronomy and agriculture to provide plants with the essential microelement selenium, which is necessary for the normal growth and development of crops.

Keywords: selenium; nanoparticles; germination percentage; sprout length; root length; Hordéum vulgáre; seeds; barley

\section{Introduction}

The applications of nanotechnology are becoming more widespread in various industries. Agriculture is one of the significant areas for the potential introduction of new nanomaterials, which is connected with the digitalization of agriculture and the use of the latest applied information methods and technologies. The research and development of high-performance nanostructured adsorbent sensors for selective detection of trace 
elements and heavy metals in various media and materials used in agriculture is promising [1-9]. Another promising area is the use of nanoparticles to improve the productivity of crops $[10,11]$ and the production of seed dressing agents $[4,12,13]$. A promising direction for the practical application of nanotechnology in agriculture is the use of metal nanoparticles for pre-sowing treatment of agricultural plant seeds since the pre-sowing treatment of seeds is one of the simplest ways to improve the quality of seed and increase crop yields. Nanoparticles cause changes in several metabolic pathways that affect plant growth and subsequent development. Nanoparticles are involved in the synthesis of proteins, carbohydrates, fats, and vitamins. They raise the content of chlorophyll in leaves, as well as improve the process of photosynthesis. It has been suggested that metal nanoparticles can also neutralize various toxic substances in the soil [14-16].

Nanoparticles have a positive effect on seed development and sowing quality. Under their influence, plants become more resistant to adverse conditions, drought, disease, and pests. Studies show that nanoparticles significantly stimulate the germination and growth of seedlings in the early stages of ontogenesis [17-19]. The effect of nanoparticles on plant development can be dose dependent. For example, it was shown that with an increase in the concentration of silver nanoparticles, the growth of seedlings can slow down in comparison with the control [20-22]. Additionally, their toxic effect may depend on the size of nanoparticles [23]. For example, it was experimentally confirmed that small silver nanoparticles with a diameter of $6 \mathrm{~nm}$ are more toxic than large ones $(20-1000 \mathrm{~nm})[24,25]$.

Special attention is paid to the study of the effects of essential trace elements such as selenium. This element is important for the full functioning of the plant organism [26,27]. The following forms of Se can be used in agriculture-selenates, selenites, selenomethionine (SeMet), methioselenocysteine (MeSeCys) and nanoscale Se. The authors of [28] note that nanoscale selenium is the most promising form of selenium.

The effect of selenium nanoparticles on different plant species can vary greatly depending on the stage of plant growth, the duration of exposure, and also the shape, size, chemical composition, concentration, surface structure, aggregation and solubility of the nanoparticle [29,30]. Earlier studies have shown that selenium nanoparticles can enhance antioxidant potential [28], promote plant growth $[16,31,32]$ and positively affect the quality and quantity of the resulting crop [33,34].

Selenium can have both a positive effect and cause serious negative effects on plant organisms, strictly depending on the concentration of Se and the type of plant $[35,36]$. However, at the level of the entire plant, an excess of selenium causes chlorosis, wilting and stunting of shoots and roots. Selenium disrupts both non-proteomic processes (for example, lipid peroxidation and changes in the redox status) and proteomic (deformed selenoproteins) [37], as well as protein damage associated with general abiotic stress (oxidized or nitrated proteins) [38,39]. The current levels of selenium in plant tissues usually exceed $5 \mathrm{mg} / \mathrm{kg}$, but the tolerance to selenium in agricultural plants varies greatly. For rice, the selenium concentration of $2 \mathrm{mg} / \mathrm{kg}$ was toxic [40], wheat showed toxic symptoms at $4.9 \mathrm{mg} / \mathrm{kg}$, while Dutch clover tolerated $330 \mathrm{mg} / \mathrm{kg}$ of selenium in tissues [41]. The effect of Se nanoparticles on wheat, rice, corn, tomatoes, potatoes, onions, lettuce and others is considered in [28].

It was shown in [41] that the use of Se nanoparticles as a fertilizer has a favorable effect on the resistance of plants to temperature increases (hyperthermia). It is shown that, in plant samples of Raphanus sativus var cultures, Sativus, Solanum melongena and S. Lycopersicum grown with the addition of Se nanoparticles $(10 \mu \mathrm{g} / \mathrm{kg})$, the surface area of the leaf blade is two times larger than that of the plants of the control group. The surface area of the leaf plate of a C. sativus culture plant grown using Se nanoparticles increased by almost 50\% compared to the control. In the case of Capsicum annuum culture, the addition of Se nanoparticles did not have a significant effect on the development of plants under hyperthermia conditions.

Thus, the study of pre-sowing treatment of seeds with various forms of selenium in order to avoid the negative toxic effects of the preparation of selenium nanoparticles 
stabilized with PVP C15 ( $8 \pm 2 \mathrm{kDa})$ and ascorbic acid is an urgent and unresolved problem. This work is devoted to the study of the production of stabilized PVP with $15(8=2 \%)$ selenium nanoparticles and the effect of ascorbic acid on morphofunctional parameters during germination of barley seeds of Hordeum vulgare. This crop is particularly chosen because $70 \%$ of farm animal feed consists of barley, and this crop is also part of the insurance fund of the Russian Federation.

\section{Materials and Methods}

\subsection{Synthesis of Preparation of Selenium Nanoparticles Stabilized by PVP C15 (8 $\pm 2 \mathrm{kDa})$ and} Ascorbic Acid

Reagent grade chemicals and grade A glassware were used in the present study. The conductivity of distilled water used in experiments was less than $2 \mu \mathrm{S} / \mathrm{cm}$ [42]. The synthesis of the preparation of selenium nanoparticles stabilized by polyvinylpyrrolidone (PVP C15 with an average mol wt $8 \pm 2 \mathrm{kDa}$ ) was conducted using the chemical reduction method [43,44]. In total, $0.25 \mathrm{~g}$ of selenous acid (Interkhim LLC, St. Petersburg, Russia) and $2.5 \mathrm{~g}$ of PVP C15 (8 $\pm 2 \mathrm{kDa}$ ) (AK Sintvita LLC, Tula, Russia) were dissolved in $20 \mathrm{~mL}$ of water and stirred until complete dissolution for $50 \mathrm{~min}$ at room temperature. Next, a reducing agent solution was prepared. For this, $1.4 \mathrm{~g}$ of ascorbic acid (ComponentReactive LLC, Moscow, Russia) was dissolved in $10 \mathrm{~mL}$ of water. After the complete dissolution of the substances, both solutions were mixed with vigorous stirring. The resulting sol of selenium nanoparticles was stirred for $15 \mathrm{~min}$. Next, the resulting sample was poured into an opaque brown glass container.

\subsection{Samples Measurement}

The size and shape of the preparation of selenium nanoparticles stabilized by PVP C15 $(8 \pm 2 \mathrm{kDa})$ and ascorbic acid were determined by transmission electron microscopy on a JEM 100B microscope (JEOL, Akishima, Japan). Sample preparation consisted of diluting the solutions of nanosized selenium stabilized by PVP C15 (8 $\pm 2 \mathrm{kDa})$ and ascorbic acid to weak opalescence, after which the resulting solution was applied to a carbon-coated measuring grid. After drying, the mesh was placed on the stage of an electron microscope.

The hydrodynamic radius of the synthesized preparation of selenium nanoparticles, stabilized by PVP C15 ( $8 \pm 2 \mathrm{kDa}$ ) and ascorbic acid, was measured by the dynamic light scattering method using the photon correlation spectrometer Photocor Complex (Photocor, Moscow, Russia).

The $\xi$-potential of the preparation was studied by acoustic and electroacoustic spectroscopy at the DT-1202 facility (Dispersion technology inc., New York, NY, USA).

The concentration of Se nanoparticles was determined by inductively coupled plasma mass spectroscopy using a time-of-flight SurfaceSeer-S Kore technology mass spectrometer.

The optical absorption spectra of selenium sols were measured by spectrophotometry with an SF-56 spectrophotometer (OKB LOMO, Saint Petersburg, Russia).

The following parameters of measurement were used:

- $\quad$ wavelength range: 190-1100 nm;

- $\quad$ sampling frequency: $1 \mathrm{~nm}$;

- $\quad$ gap width: $6 \mathrm{~nm}$;

- measured value: absorption.

$X$-ray powder diffraction analysis was conducted using $X$-ray diffractometer Empyrean (PANalytical, Almelo, The Netherlands) in order to determine the crystalline structure of nanoparticles. Preparation of samples for X-ray diffraction analysis included the addition of selenium sol to aerosil powder $\left(\mathrm{SiO}_{2}\right)$ and homogenization of the powder containing selenium. The parameters of the measurement were as follows:

- Copper cathode;

- Emission wavelength 1.54 A;

- Current $35 \mathrm{~mA}$;

- $\quad$ Voltage $40 \mathrm{kV}$; 
- $2 \theta$ measurement range $10^{\circ}-90^{\circ}$;

- $2 \theta$ sampling frequency: $0.01^{\circ}$.

Elemental analysis of preparation of selenium nanoparticles, stabilized by PVP C15 $(8 \pm 2 \mathrm{kDa})$ and ascorbic acid samples was carried out using energy-dispersive X-ray spectroscopy on a MIRA3-LMH scanning electron microscope (Tescan, Brno, Czech Republic) with an AZtecEnergy Standard X-max 20 system for determining the elemental composition. Sample preparation was carried out as follows: a double-sided conductive carbon tape was glued to a standard instrument table. The dry preparation of nanoselene was obtained by freeze-drying using a 10M2-M1 refrigerated drying machine (Genyond, Shanghai, China).

A dried powder of selenium nanoparticles stabilized by PVP C15 ( $8 \pm 2 \mathrm{kDa})$ and ascorbic acid was then applied to a conducting carbon tape. Furthermore, a thin gold coating with a thickness of about $10 \mathrm{~nm}$ was applied to the selenium powder.

\subsection{Treatment of the Seeds}

In the experiment, we used seeds of the Hordeum vulgare L. culture, stored for more than 10 years, with reduced morphological and functional characteristics. The seeds were purchased from the Research Institute of Agriculture (SNIISH, Stavropol, Russian Federation). Previously, the seeds were not subjected to additional processing. The seeds were treated with solutions of selenium nanoparticles, ascorbic acid, polyvinylpyrrolidone, selenous acid, with various concentrations. In the control sample, the seeds were treated with distilled water. The concentrations of substances in solutions used in the seed treatment are presented in Table 1.

Table 1. Concentrations of substances in seed treatment solutions.

\begin{tabular}{cccccc}
\hline Dressing Agent & \multicolumn{5}{c}{ Concentration, $\mu \mathrm{g} / \mathrm{mL}$} \\
\hline Ascorbic Acid & 4.7 & 46.7 & 466.7 & 4666.7 & $46,666.7$ \\
Selenous acid & 0.76 & 7.6 & 76.0 & 760.0 & 7600.0 \\
Selenium nanoparticles & 0.465 & 4.65 & 46.5 & 465.0 & 4650.0 \\
PVP C15 (8 $\pm 2 \mathrm{kDa})$ & 7.7 & 77.0 & 770.0 & 7700.0 & $77,000.0$ \\
\hline
\end{tabular}

Hordeum vulgare L. seeds treated with solutions of various concentrations were placed in a thermostat at a constant temperature of $20^{\circ} \mathrm{C}$ without illumination. Each sample contained 100 seeds. Seventy-two hours after treatment, the percentage of germinated seeds was calculated, the lengths of the roots and shoots were measured, the number of roots was determined, and the obtained data were then compared with the control.

Statistical processing of the experimental results was carried out using Statistica 12.0 software (StatSoft). To assess the significance of dressing agents' concentration as a factor affecting the seeds' germination percentage, the length of roots and shoots, and the number of roots, intragroup and intergroup analyses of variance (ANOVA) were carried out. The nature of the distribution of quantitative characteristics was determined using the Shapiro-Wilk test; the equality of variances was determined using the Leuven test. Tukey's multiple comparison test was used to determine the significant difference between the samples. To compare quantitative characteristics in the intergroup analysis of variance, the Kruskal-Wallis test was used. Quantitative values were assessed using the median (Me) and the 25th and 75th percentiles. The critical level of significance (p) was taken equal to 0.05 .

\section{Results and Discussion}

\subsection{Selenium Nanoparticles Characterization}

Often scientific articles describe results of studies of nanoparticles that do not contain a stabilizer [45-47]. However, when used in real environments, such particles undergo processes of aggregation, coagulation and sedimentation, with the subsequent loss of their 
unique properties due to dimensional effects $[48,49]$. Following this, a preparation of selenium nanoparticles stabilized by PVP C15 ( $8 \pm 2 \mathrm{kDa})$ and ascorbic acid was used in this work. The chemical reactions occurring during the preparation of the drug are shown in Figure 1A,B.

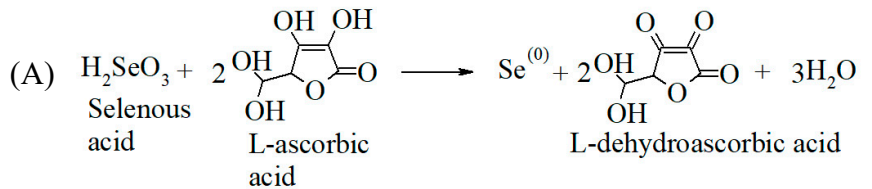

(B)

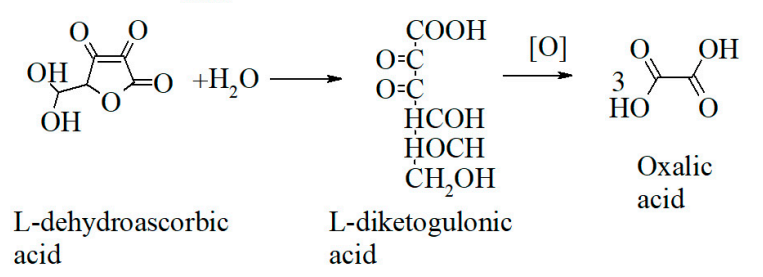

\section{(C)}

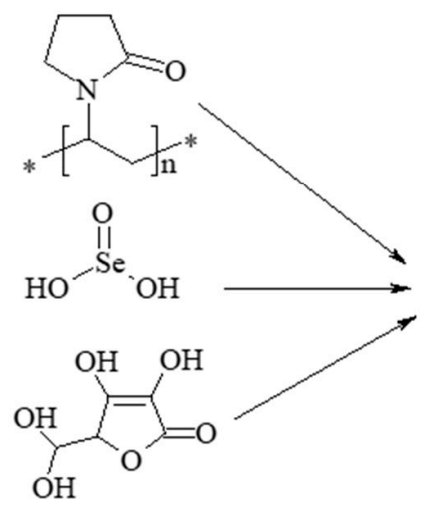

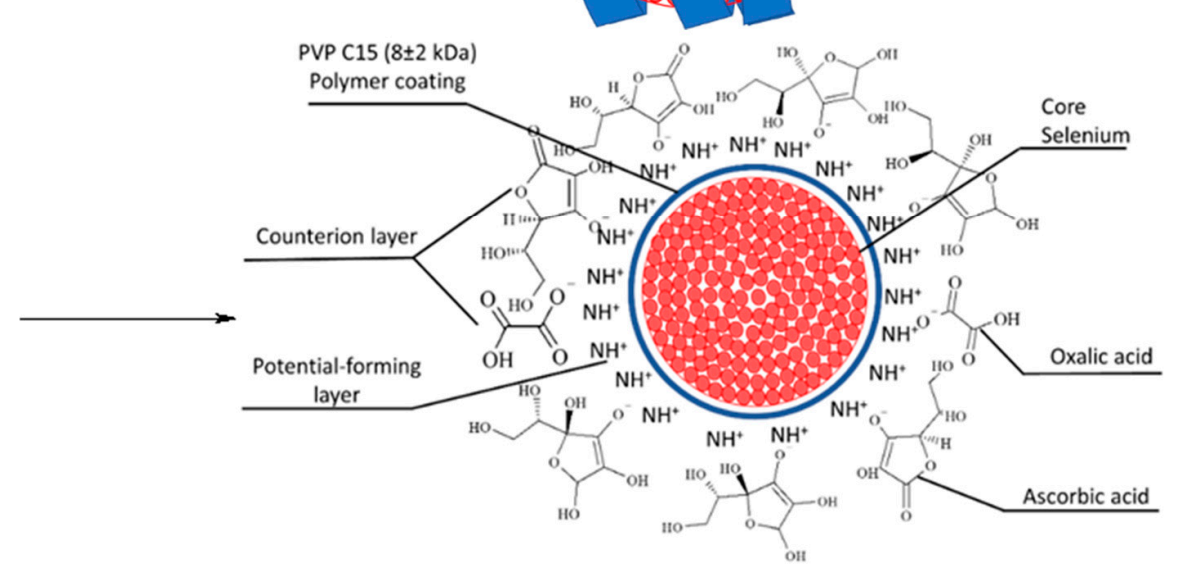

Figure 1. Synthesis of preparation of selenium nanoparticles stabilized with PVP C15 (8 $\pm 2 \mathrm{kDa})$ and ascorbic acid: (A) reaction of reduction of selenic acid with ascorbic acid to elemental selenium; (B) transformation of dehydroascorbic acid into oxalic acid; (C) structure of the double electric layer of the preparation of selenium nanoparticles stabilized with PVP C15 (8 $\pm 2 \mathrm{kDa}$ ) and ascorbic acid; (D) schematic image of the polymer stabilization of selenium nanoparticles.

The structure of the particles of the preparation of selenium nanoparticles stabilized by PVP C15 $(8 \pm 2 \mathrm{kDa})$ and ascorbic acid is shown in Figure $1 \mathrm{C}$. The core consists of selenium particles, and the potential forming layer is formed by the $\mathrm{NH}+$ groups of the PVP C15 pyrrolidone ring $(8 \pm 2 \mathrm{kDa})$, which is confirmed by the study of the $\zeta$-potential, the value of which was $+58.56 \mathrm{mV}$. The anti-ion layer consists of oxalic acid ions, which are obtained via the oxidation of ascorbic acid (Figure 1B), and non-reacting ascorbic acid ions, taken in excess to form a preparation with increased antioxidant properties. A schematic representation of the polymer stabilization of selenium nanoparticles stabilized by PVP C15 (8 $\pm 2 \mathrm{kDa})$ and ascorbic acid is shown in Figure 1D.

To determine the morphology of selenium nanoparticles in the obtained samples, the dried sol was investigated using transmission electron microscopy. A TEM image of selenium nanoparticles preparation stabilized by PVP C15 ( $\pm 2 \mathrm{kDa})$ and ascorbic acid is shown in Figure 2A. It was found that nanoparticles have spherical shapes, monodisperse distribution, and diameters of about $70 \pm 10 \mathrm{~nm}$. 

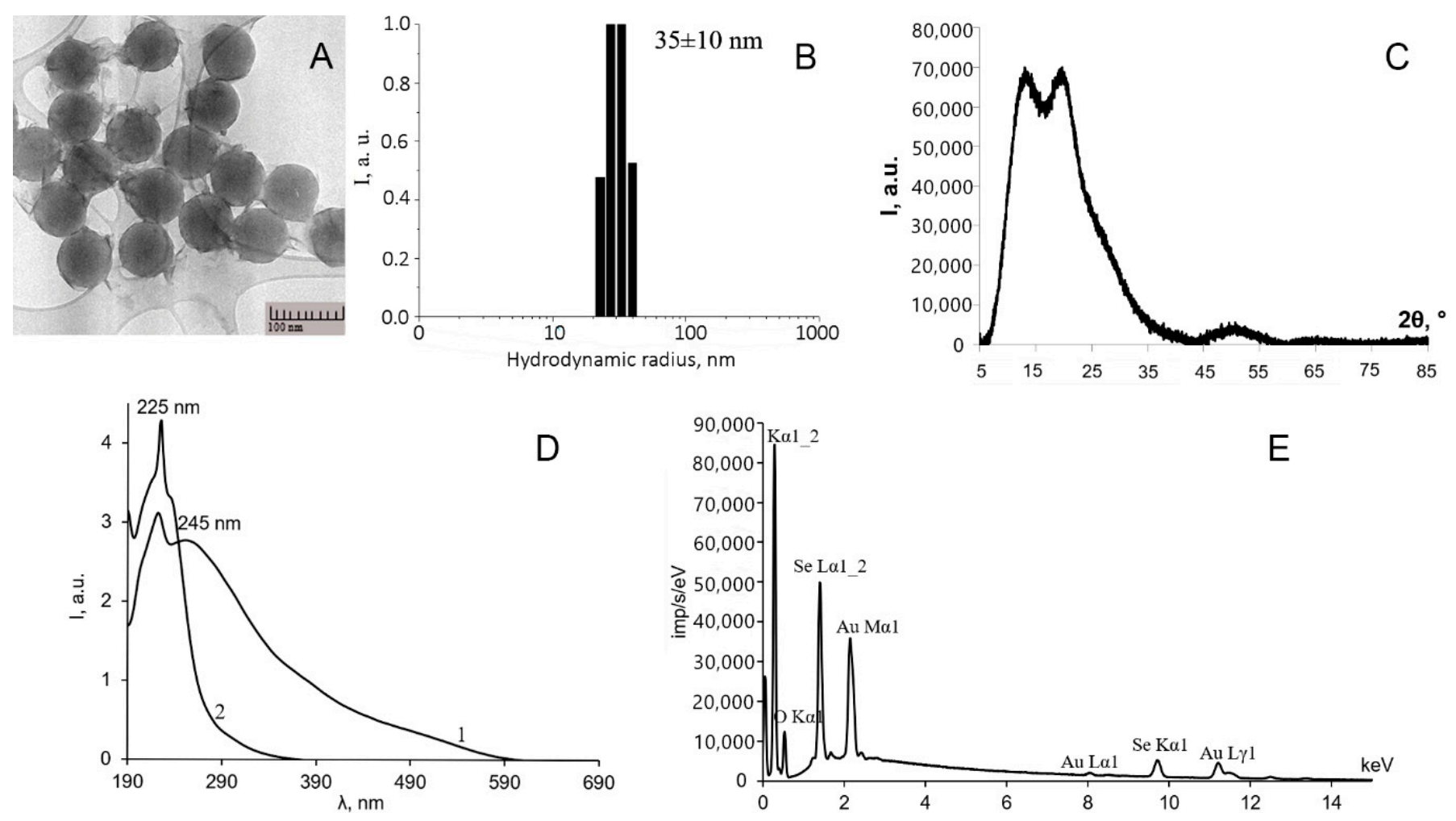

Figure 2. Elemental composition and structure of preparation of selenium nanoparticles stabilized with PVP C15 (8 \pm 2 kDa) and ascorbic acid: (A) TEM micrograph; (B) histogram of distribution of hydrodynamic radius; (C) diffractogram; (D) absorption spectra of a selenium sol sample (1) and an aqueous solution of polyvinylpyrrolidone (2); (E) EDX spectra of the dried nanoselenium sol sample.

Measurements of the selenium nanoparticles' hydrodynamic radius by dynamic light scattering confirm the data obtained using transmission microscopy. Figure 2B shows a histogram of the distribution of the nanoparticles' hydrodynamic radii.

According to the measurement results, the average hydrodynamic radius of the preparation of selenium nanoparticles stabilized with PVP C15 (8 $\pm 2 \mathrm{kDa})$ and ascorbic acid was $35 \mathrm{~nm}$; the distribution was monomodal and the particles were characterized by a moderate polydispersity of $\pm 10 \mathrm{~nm}$.

Next, the phase composition of the dried preparation of selenium nanoparticles stabilized with PVP C15 ( $8 \pm 2 \mathrm{kDa})$ and ascorbic acid was determined. Figure $2 \mathrm{C}$ shows the diffractogram of a selenium sol sample mixed with aerosil.

X-ray phase analysis showed that the preparation of selenium nanoparticles stabilized with PVP C15 $(8 \pm 2 \mathrm{kDa})$ and ascorbic acid has a rhombohedral crystal lattice, space group $\mathrm{R}-3$. The low intensity of the X-ray characteristic peaks indicates that the structure of the substance is strongly amorphous. An intense broad peak with a maximum at about $22^{\circ}$ corresponds to amorphous $\mathrm{SiO}_{2}$. The presence of this peak is associated with a feature of sample preparation-the need to use aerosil as a substrate for selenium nanoparticles.

Next, the optical properties of the solution preparation of selenium nanoparticles stabilized with PVP C15 ( $8 \pm 2 \mathrm{kDa})$ and ascorbic acid were investigated. Figure 2D shows the optical absorption spectra in the visible region of a selenium sol sample and an aqueous solution of PVP.

Analysis of absorption spectra showed the presence of a resonance peak at $245 \mathrm{~nm}$ corresponding to preparation of selenium nanoparticles stabilized with PVP C15 $(8 \pm 2 \mathrm{kDa})$ and ascorbic acid, which was also noted in $[44,50,51]$. Additionally, the spectrum of the selenium sol sample contains an absorption peak at $225 \mathrm{~nm}[52,53]$. This peak is associated with the absorption of PVP, which was presented in the sample as a nanoparticle stabilizer. 
To assess the elemental composition, as well as the selenium content in the sample, energy dispersive $X$-ray spectroscopy was performed. The results of the EDX spectroscopy of a dried selenium sol sample are presented in Figure 2E, the analysis of which made it possible to determine the mass concentrations of elements in the sample-mass \%: $\mathrm{C}-72.92, \mathrm{O}-20.03$, and $\mathrm{Se}-7.05$.

Analysis of the data showed the presence of the Se element in the sample, as well as carbon and oxygen, which is associated with the presence of ascorbic acid and the PVP stabilizer in the composition of dry sample. The mass fraction of selenium in the sample was $7.05 \mathrm{wt}$. \%. The spectrum contains lines corresponding to $\mathrm{Au}$, the presence of which is due to the need for deposition of gold coating for analysis. Gold was excluded from the analysis when calculating the contents of elements in the sample.

\subsection{Effect of Preparation of Selenium Nanoparticles Stabilized with PVP C15 ( $8 \pm 2 \mathrm{kDa})$ and} Ascorbic Acid on Morphofunctional Parameters of Seed Germination

At the first stage, the germination percentage as well as the morphofunctional parameters of Hordeum vulgare L. seeds germinated in water (Control group), were studied. This measurement was carried out in five replicates $(n=5)$. The results are presented in Table 2 and Figure 3.

Table 2. Morphological and functional parameters of seed germination in water.

\begin{tabular}{ccccc}
\hline $\begin{array}{c}\text { Num. of } \\
\text { Control Probe }\end{array}$ & $\begin{array}{c}\text { Percentage of } \\
\text { Germinated } \\
\text { Seeds, } \%\end{array}$ & $\begin{array}{c}\text { Number of } \\
\text { Roots }\end{array}$ & $\begin{array}{c}\text { Average Root } \\
\text { Length, mm }\end{array}$ & $\begin{array}{c}\text { Average Shoot } \\
\text { Length, mm }\end{array}$ \\
\hline 1 & $44.98 \pm 0.92$ & $3.68 \pm 0.50$ & $10.95 \pm 2.03$ & $7.41 \pm 0.40$ \\
2 & $45.01 \pm 0.07$ & $3.62 \pm 0.49$ & $10.99 \pm 1.91$ & $7.42 \pm 0.56$ \\
3 & $45.06 \pm 1.01$ & $3.70 \pm 0.51$ & $10.91 \pm 1.87$ & $7.38 \pm 0.54$ \\
4 & $44.97 \pm 0.93$ & $3.68 \pm 0.46$ & $10.89 \pm 1.98$ & $7.43 \pm 0.58$ \\
5 & $44.96 \pm 1.08$ & $3.69 \pm 0.52$ & $10.95 \pm 1.86$ & $7.40 \pm 0.61$ \\
\hline
\end{tabular}

The data presented are the means of five replicates $(n=5) \pm$ standard error. Number of seeds in one sample $\mathrm{N}=100$.
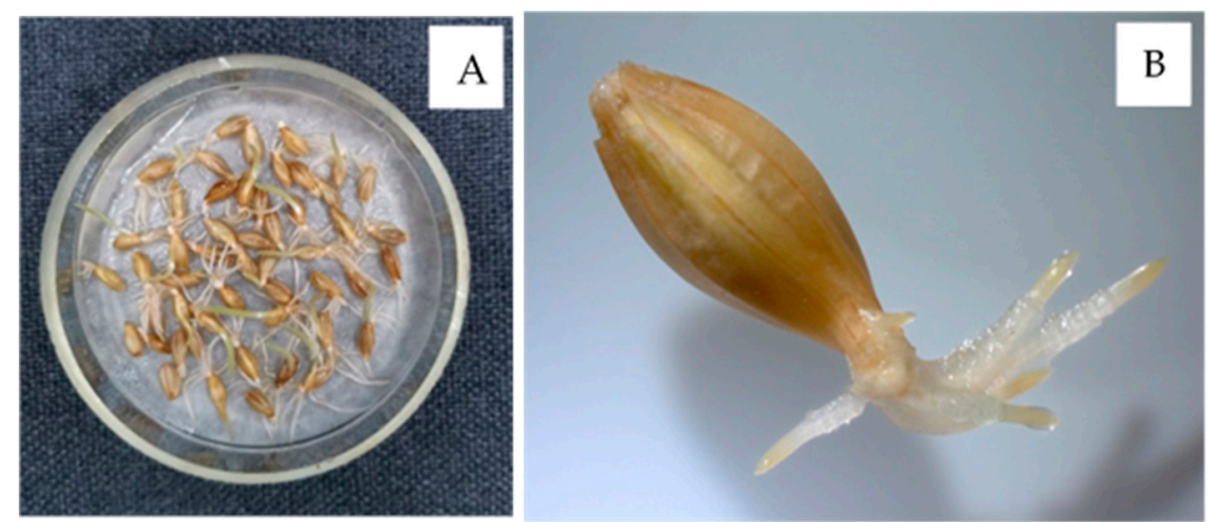

Figure 3. Photographs of Hordeum vulgare seeds: (A) A sample of seeds of the Hordeum vulgare L. culture treated with Se nanoparticles in a petri dish; (B) a single germinated barley seed.

The analysis of the data confirmed that the seeds of the Hordeum vulgare L. culture, stored for more than 10 years, have reduced morphological and functional characteristics, so the percentage of germination for them is less than $50 \%$. The choice of seeds with reduced morphofunctional characteristics is due to the presence of a large number of studies that use standard seeds with normative and permissible morphofunctional characteristics to study the phytotoxicity of selenium compounds. However, at low selenium concentrations, as shown in [53-55], these compounds do not exhibit toxic properties and normalize metabolic processes, being the main part of many selenium-containing enzymes, which can be found by the improving the morphofunctional parameters of seeds and young plants. 
This work is a part of a series of laboratory studies aimed at studying the effect of nanoselene preparations on improving the morphofunctional parameters of seeds and plants in extreme conditions with high and low temperatures, high salinity of soils, low and high humidity, and many others. With subsequent field research and the formation of a regulatory and recommendatory framework for the use of selenium preparations in agriculture in regions with extreme environmental conditions, this allows one to neutralize the impact on agriculture of significant climatic fluctuations.

Since the preparation of selenium nanoparticles, stabilized by PVP C15 $(8 \pm 2 \mathrm{kDa})$ and ascorbic acid is a single bound system, the influence of individual components on the morphofunctional characteristics of seeds of Hordéum vulgáre was studied.

The dependencies of the measured morphological and functional characteristics of the treated seeds on the concentration of dressing agents are shown in Figure 4 and Table 3. For clarity of data presentation, instead of the actual concentration values on the $\mathrm{X}$-axis, the decimal logarithm of the concentration was taken.

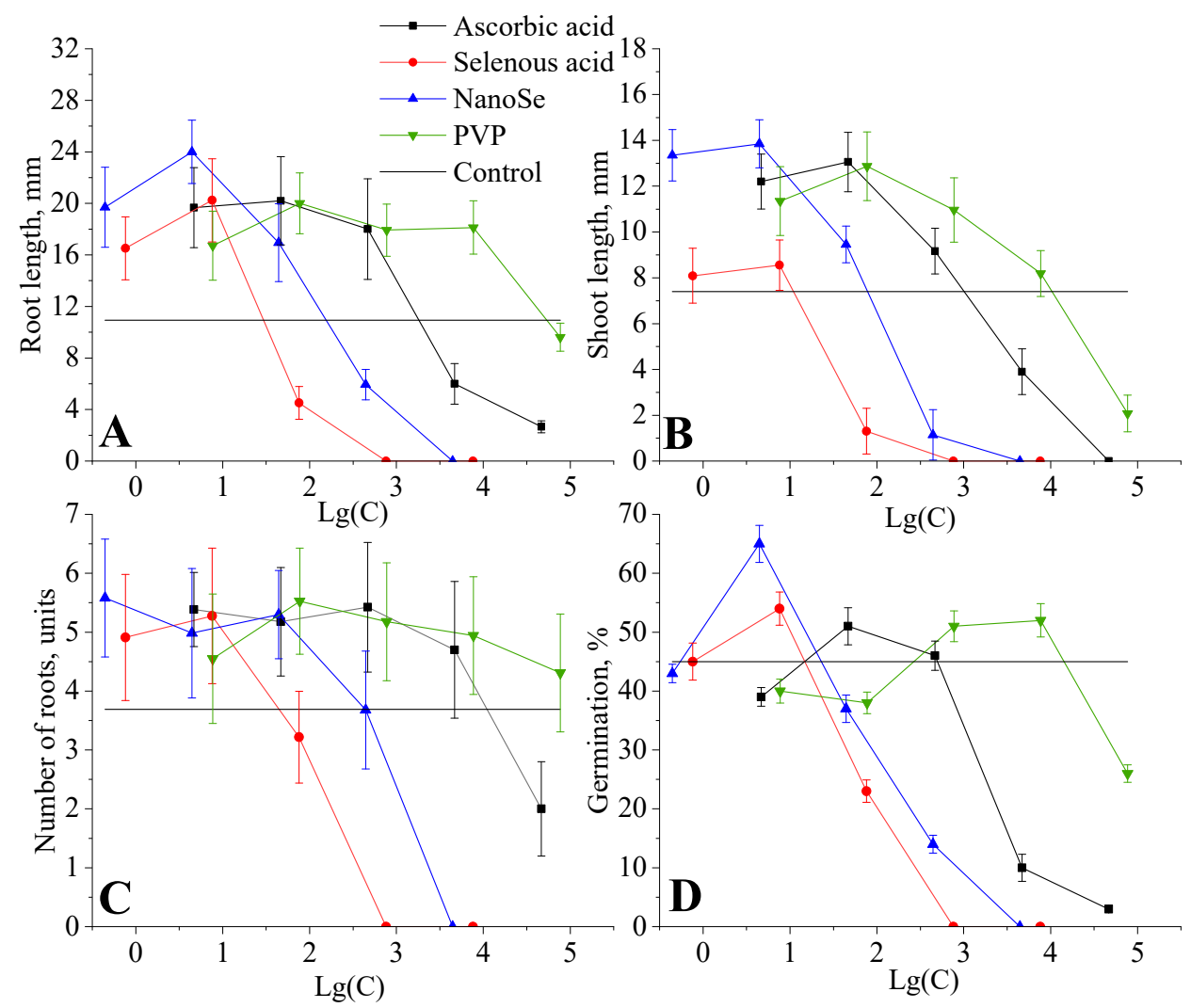

Figure 4. Dependencies of morphological and functional characteristics of the treated seeds on the concentration of dressing agents (72 $\mathrm{h}$ incubation): (A) dependencies of the root length on the logarithm of the seed dressing agents' concentrations; (B) dependencies of the shoot length on the logarithm of the seed dressing agents' concentrations, $(\mathbf{C})$ dependencies of the number of roots on the logarithm of the seed dressing agents' concentrations, (D) dependencies of germination percentage on the logarithm of seed dressing agents' concentrations $(p<0.05)$. 
Table 3. Influence of the dressing agent's concentration on the morphological and functional characteristics of Hordeum vulgare L. seeds.

\begin{tabular}{|c|c|c|c|c|c|c|}
\hline $\begin{array}{c}\text { Dressing } \\
\text { Agent }\end{array}$ & $\begin{array}{l}\text { Concentration } \\
\text { (C), } \mu \mathrm{g} / \mathrm{mL}\end{array}$ & $\operatorname{Lg}(C)$ & $\begin{array}{c}\text { Germination } \\
\text { Percentage, } \%\end{array}$ & $\begin{array}{c}\text { Root Length, } \\
\text { mm }\end{array}$ & $\begin{array}{c}\text { Shoot Length, } \\
\text { mm }\end{array}$ & $\underset{\text { Roots }}{\text { Number of }}$ \\
\hline Ascorbic acid & $\begin{array}{c}\text { Control } \\
4.7 \\
46.7 \\
466.7 \\
4666.7 \\
46666.7 \\
\end{array}$ & $\begin{array}{c}-\overline{-2.33} \\
-1.33 \\
-0.33 \\
0.67 \\
1.67\end{array}$ & $\begin{array}{c}45.00 \pm 1.00 \mathrm{ab} \\
39.00 \pm 1.58 \mathrm{~b} \\
51.00 \pm 3.15 \mathrm{a} \\
46.00 \pm 2.47 \mathrm{a} \\
10.00 \pm 2.30 \mathrm{~d} \\
3.00 \pm 0.58 \mathrm{c}\end{array}$ & $\begin{array}{c}10.94 \pm 1.92 \mathrm{c} \\
19.66 \pm 3.10 \mathrm{a} \\
20.20 \pm 3.42 \mathrm{a} \\
18.00 \pm 3.90 \mathrm{a} \\
6.00 \pm 1.58 \mathrm{~b} \\
2.67 \pm 0.46 \mathrm{~b}\end{array}$ & $\begin{array}{c}7.40 \pm 0.59 \mathrm{bc} \\
12.21 \pm 2.95 \mathrm{de} \\
13.06 \pm 2.98 \mathrm{e} \\
9.17 \pm 1.83 \mathrm{~cd} \\
3.90 \pm 1.38 \mathrm{ab} \\
0.00 \pm 0.00 \mathrm{a}\end{array}$ & $\begin{array}{c}3.69 \pm 0.47 \mathrm{~d} \\
5.38 \pm 0.63 \mathrm{a} \\
5.18 \pm 0.92 \mathrm{ab} \\
5.42 \pm 1.10 \mathrm{a} \\
4.70 \pm 1.16 \mathrm{~b} \\
2.00 \pm 0.80 \mathrm{c}\end{array}$ \\
\hline Selenous acid & $\begin{array}{c}\text { Control } \\
0.76 \\
7.6 \\
76.0 \\
760.0 \\
7600.0 \\
\end{array}$ & $\begin{array}{c}-\overline{3.12} \\
-2.12 \\
-1.12 \\
-0.12 \\
0.88 \\
\end{array}$ & $\begin{array}{c}45.00 \pm 1.00 \mathrm{a} \\
45.00 \pm 3.15 \mathrm{a} \\
54.00 \pm 2.81 \mathrm{a} \\
23.00 \pm 1.91 \mathrm{c} \\
0.00 \pm 0.00 \mathrm{~b} \\
0.00 \pm 0.00 \mathrm{~b}\end{array}$ & $\begin{array}{c}10.94 \pm 1.92 \mathrm{c} \\
16.51 \pm 2.44 \mathrm{~d} \\
20.24 \pm 3.22 \mathrm{e} \\
4.52 \pm 1.27 \mathrm{~b} \\
0.00 \pm 0.00 \mathrm{a} \\
0.00 \pm 0.00 \mathrm{a}\end{array}$ & $\begin{array}{l}7.40 \pm 0.59 \mathrm{~b} \\
8.09 \pm 1.87 \mathrm{~b} \\
5.56 \pm 1.76 \mathrm{~b} \\
1.30 \pm 1.03 \mathrm{a} \\
0.00 \pm 0.00 \mathrm{a} \\
0.00 \pm 0.00 \mathrm{a}\end{array}$ & $\begin{array}{l}3.69 \pm 0.47 \mathrm{~b} \\
4.94 \pm 1.07 \mathrm{c} \\
5.28 \pm 1.15 \mathrm{c} \\
3.22 \pm 0.78 \mathrm{~b} \\
0.00 \pm 0.00 \mathrm{a} \\
0.00 \pm 0.00 \mathrm{a}\end{array}$ \\
\hline $\begin{array}{c}\text { Selenium } \\
\text { nanoparticles }\end{array}$ & $\begin{array}{c}\text { Control } \\
0.465 \\
4.65 \\
46.5 \\
465.0 \\
4650.0 \\
\end{array}$ & $\begin{array}{c}-\overline{-} \\
-3.33 \\
-2.33 \\
-1.33 \\
-0.33 \\
0.67\end{array}$ & $\begin{array}{c}45.00 \pm 1.00 \mathrm{a} \\
43.00 \pm 2.58 \mathrm{a} \\
65.00 \pm 3.15 \mathrm{~d} \\
37.00 \pm 2.31 \mathrm{a} \\
14.00 \pm 1.52 \mathrm{~b} \\
0.00 \pm 0.00 \mathrm{c}\end{array}$ & $\begin{array}{c}10.94 \pm 1.92 \mathrm{~d} \\
19.70 \pm 3.11 \mathrm{~b} \\
24.07 \pm 2.46 \mathrm{a} \\
16.95 \pm 3.02 \mathrm{~b} \\
5.93 \pm 1.18 \mathrm{c} \\
0.00 \pm 0.00 \mathrm{e}\end{array}$ & $\begin{array}{l}7.40 \pm 0.59 \mathrm{~b} \\
13.35 \pm 2.96 \mathrm{c} \\
13.85 \pm 2.95 \mathrm{c} \\
9.46 \pm 1.86 \mathrm{~b} \\
1.14 \pm 0.52 \mathrm{a} \\
0.00 \pm 0.00 \mathrm{a}\end{array}$ & $\begin{array}{l}3.69 \pm 0.47 \mathrm{~b} \\
5.58 \pm 1.07 \mathrm{a} \\
4.98 \pm 1.11 \mathrm{a} \\
5.30 \pm 0.74 \mathrm{a} \\
3.68 \pm 1.01 \mathrm{~b} \\
0.00 \pm 0.00 \mathrm{c}\end{array}$ \\
\hline $\begin{array}{c}\text { PVP C15 }(8 \pm 2 \\
\text { kDa) }\end{array}$ & $\begin{array}{c}\text { Control } \\
7.7 \\
77.0 \\
770.0 \\
7700.0 \\
77000.0\end{array}$ & $\begin{array}{c}-\overline{-} \\
-1.11 \\
-0.11 \\
0.89 \\
1.89\end{array}$ & $\begin{array}{l}45.00 \pm 1.00 \mathrm{ab} \\
40.00 \pm 2.04 \mathrm{ab} \\
38.00 \pm 1.83 \mathrm{ac} \\
51.00 \pm 2.61 \mathrm{ab} \\
52.00 \pm 2.83 \mathrm{~b} \\
26.00 \pm 1.47 \mathrm{c}\end{array}$ & $\begin{array}{l}10.94 \pm 1.92 \mathrm{~b} \\
16.72 \pm 2.68 \mathrm{a} \\
20.01 \pm 2.39 \mathrm{a} \\
17.92 \pm 2.02 \mathrm{a} \\
18.13 \pm 2.06 \mathrm{a} \\
9.62 \pm 1.01 \mathrm{~b}\end{array}$ & $\begin{array}{c}7.40 \pm 0.59 \mathrm{ac} \\
11.35 \pm 1.89 \mathrm{ab} \\
12.87 \pm 2.10 \mathrm{~b} \\
10.96 \pm 2.27 \mathrm{ab} \\
8.19 \pm 1.28 \mathrm{a} \\
2.08 \pm 1.44 \mathrm{c}\end{array}$ & $\begin{array}{c}3.69 \pm 0.47 \mathrm{~b} \\
4.55 \pm 1.08 \mathrm{ab} \\
5.53 \pm 0.89 \mathrm{c} \\
5.18 \pm 1.09 \mathrm{ac} \\
4.94 \pm 1.03 \mathrm{ac} \\
4.31 \pm 1.05 \mathrm{ab}\end{array}$ \\
\hline
\end{tabular}

The data presented are the means of five replicates $(n=5) \pm$ standard error. Different letters indicate a statistically significant difference $(p<0.05)$ between the samples within the group.

Figure $4 \mathrm{~A}$ shows the dependencies of the root length on the logarithm of the seed dressing agents' concentrations.

The effect of the concentration of various seed dressing agents on the root length of Hordeum vulgare L. seeds is described by non-linear plots. When seeds were treated with ascorbic acid, selenous acid, preparation of selenium nanoparticles stabilized by PVP C15 $(8 \pm 2 \mathrm{kDa})$ and ascorbic acid, and PVP, the maximum root lengths reached at $\mathrm{Lg}(\mathrm{C})$ were equal to $1.66,0.88,0.67$, and 1.88 , respectively, which correspond to concentrations of 46.7 , $7.6,4.65$, and $77.0 \mu \mathrm{g} / \mathrm{mL}$. At these concentrations, a significant increase in root length (from 8 to $12 \mathrm{~mm}$ ) as compared to the control group was recorded $(p<0.05)$. An increase in the concentration of the dressing agents led to a decrease in the length of the roots below the control group.

Figure $4 \mathrm{~B}$ presents the dependencies of the shoot length on the logarithm of the seed dressing agents' concentrations.

In all samples, a similar tendency was observed: with a decrease in the concentration of active substances, an increase in the shoot length occurs. The greatest delay in growth was observed for selenous acid, which is in good agreement with the results described in [56,57], and confirms its high toxicity and the impossibility of using it as a selenium source.

At $\operatorname{Lg}(C)$ of selenium nanoparticles equal to 0.67 , which corresponds to a concentration of $4.65 \mu \mathrm{g} / \mathrm{mL}$, a statistically significant $(p<0.05)$ maximum shoot length was recorded; the excess over the control was more than $87 \%$.

The dependence of the number of roots on the $\operatorname{Lg}(\mathrm{C})$ of seed dressing agents is presented in Figure 4C.

It was found that at the concentrations of ascorbic and selenous acids, nanoselenium, stabilized by PVP C15 ( $8 \pm 2 \mathrm{kDa}$ ) and ascorbic acid, and PVP equal to 12 590.0, 56.0, 465.0 , and $77,000.0 \mu \mathrm{g} / \mathrm{mL}$, respectively, there was an increase in the number of roots in comparison with the control group. It is also worth noting that in the samples with selenium nanoparticles in the $\operatorname{Lg}(\mathrm{C})$ range from 2.67 to $3.67(465.0$ to $4650.0 \mu \mathrm{g} / \mathrm{mL})$, the values of the number of roots were lower than the control ones. However, these values are 
an order of magnitude higher than values for selenous acid $(76.0-7600.0 \mu \mathrm{g} / \mathrm{mL})$, which is associated with its toxic properties and characterizes the relatively lower toxicity of selenium nanoparticles.

This is confirmed in the works [58,59], which present studies of the phytotoxicity, accumulation and transformation of various forms of selenium in garlic: selenite $\left(\mathrm{Se}^{+4}\right)$, selenate $\left(\mathrm{Se}^{+6}\right)$ and selenium nanoparticles. The authors showed that the phytotoxicity of SeNP is much lower than that of selenite and selenate. It was found that, when treated with selenate and selenite at a concentration of $10 \mathrm{mg} / \mathrm{L}$, there was a negative effect on the morphofunctional characteristics of the studied culture, but the inhibition of garlic growth by selenium nanoparticles occurred at a concentration of $50 \mathrm{mg} / \mathrm{L}$. Compared to the control group, the biomass of the groups treated with selenate, selenite, and Se nanoparticles at $50 \mathrm{mg} / \mathrm{L}$ decreased by more than $50 \%, 30 \%$, and $10 \%$, respectively.

Figure $4 \mathrm{D}$ shows the dependence of the percentage of seed germination on the logarithm of the concentration of studied substances.

The highest value of germination percentage was obtained for the sample with nanoselenium at $\operatorname{Lg}(C)=0.67$, which corresponds to a concentration of $4.65 \mu \mathrm{g} / \mathrm{mL}(p<0.05)$. With an increase in concentration in all samples, a decrease in the percentage of germination below the control group was observed, indicating a negative effect of the preparation on the morphofunctional characteristics of seeds at a concentration of more than $4.65 \mu \mathrm{g} / \mathrm{mL}$.

The results of the intergroup analysis of variance of the data are summarized in Table 4 .

Table 4. Comparison of statistical significance of differences in morphological and functional parameters of seed germination in different groups (intergroup ANOVA results) at concentration of $4.65 \mu \mathrm{g} / \mathrm{mL}$.

\begin{tabular}{|c|c|c|c|c|c|c|c|c|c|c|c|c|c|c|c|}
\hline \multirow[t]{2}{*}{ Germination Parameter } & \multicolumn{3}{|c|}{$\begin{array}{l}\text { Ascorbic Acid } \\
\text { (Group 1) }\end{array}$} & \multicolumn{3}{|c|}{$\begin{array}{l}\text { Selenous Acid } \\
\text { (Group 2) }\end{array}$} & \multicolumn{3}{|c|}{$\begin{array}{c}\text { Selenium } \\
\text { Nanoparticles } \\
\text { (Group 3) }\end{array}$} & \multicolumn{3}{|c|}{$\begin{array}{c}\text { PVP } \\
\text { (Group 4) }\end{array}$} & \multicolumn{3}{|c|}{$\begin{array}{l}\text { Control } \\
\text { (Group 5) }\end{array}$} \\
\hline & $\mathbf{M}_{\mathbf{e}}$ & 25 & 75 & $\mathbf{M}_{\mathbf{e}}$ & 25 & 75 & $\mathbf{M}_{\mathrm{e}}$ & 25 & 75 & $\mathbf{M}_{\mathrm{e}}$ & 25 & 75 & $\mathbf{M}_{\mathrm{e}}$ & 25 & 75 \\
\hline Root length & $\begin{array}{l}19.66 \\
* * * \\
\bullet \bullet \\
\Delta \Delta\end{array}$ & 19.60 & 22.00 & $\begin{array}{l}20.24 \\
* * * \\
\Delta \Delta \Delta\end{array}$ & 18.00 & 26.00 & $\begin{array}{c}24.07 \\
* * * \\
\S \S \\
\Delta \Delta \Delta\end{array}$ & 20.00 & 29.00 & $\begin{array}{c}16.72 \\
* * * \\
\# \# \# \\
\S \S \\
\bullet \bullet\end{array}$ & 14.40 & 23.00 & $\begin{array}{l}10.94 \\
\# \# \# \\
\bullet \bullet \bullet \\
\$ \$ \S \\
\Delta \Delta \Delta\end{array}$ & 10.01 & 12.25 \\
\hline Shoot length & $\begin{array}{c}12.21 \\
* * * \\
\# \#\end{array}$ & 11.00 & 14.00 & $\begin{array}{c}8.56 \\
\bullet \bullet \\
\S\end{array}$ & 0.00 & 14.00 & $\begin{array}{c}13.85 \\
* * * \\
\# \#\end{array}$ & 0.00 & 22.00 & 11.35 & 7.00 & 16.00 & $\begin{array}{l}7.44 \\
\bullet \bullet \bullet \\
\$ \$ \$ \\
\Delta \Delta\end{array}$ & 7.00 & 8.00 \\
\hline Number of roots & $\begin{array}{c}5.38 \\
* * * \\
\Delta\end{array}$ & 5.00 & 6.00 & $\begin{array}{c}5.28 \\
\Delta * * \\
\Delta\end{array}$ & 5.00 & 6.00 & $\underset{* * *}{4.98}$ & 5.00 & 6.00 & $\begin{array}{c}4.55 \\
* * * \\
\# \\
\S\end{array}$ & 4.55 & 6.00 & $\begin{array}{l}3.69 \\
\# \# \# \\
\bullet \bullet \bullet \\
\$ \$ \S \\
\Delta \Delta \Delta\end{array}$ & 3.00 & 4.00 \\
\hline Germination percentage & $\begin{array}{c}39.00 \\
* * * \\
\# \# \# \\
\bullet \bullet \bullet\end{array}$ & 38.00 & 40.00 & $\begin{array}{l}54.00 \\
\bullet \bullet \bullet \\
\S \S \S \\
\Delta \Delta \Delta\end{array}$ & 52.00 & 56.00 & $\begin{array}{l}65.00 \\
* * * \\
\# \# \# \\
\S \S \S \\
\Delta \Delta \Delta\end{array}$ & 64.00 & 66.00 & $\begin{array}{c}40.00 \\
* * \\
\# \# \# \\
\bullet \bullet \bullet\end{array}$ & 36.00 & 44.00 & $\begin{array}{l}45.00 \\
\bullet \bullet \bullet \\
\S \S \S \\
\Delta \Delta\end{array}$ & 44.00 & 46.00 \\
\hline
\end{tabular}

Significant differences from control (group 5) $p<0.05-^{*}, p<0.01$ —** $^{*}, p<0.001$ —**$^{*}$, differences from the group $1 p<0.05-\S, p<0.01-\S \S$, $p<0.001-\$ \S \S$, differences from the group $2 p<0.05-\#, p<0.01-\# \#, p<0.001-\# \#$, differences from the group $3 p<0.05-\bullet, p<0.01-\bullet \bullet$, $p<0.001-\bullet \bullet \bullet$, differences from the group $4 p<0.05-\Delta, p<0.01-\Delta \Delta, p<0.001-\Delta \Delta \Delta$. Differences between groups are considered statistically significant at $p<0.05$.

Intergroup analysis of variance of the data allowed us to assess the reliability and significance of the results. Analysis of the root length in the samples of groups 1-4 showed a statistically significant difference $(p<0.001)$ of this indicator with the control group. Taking into account the 25th and 75th percentiles, the values of the root length of the samples in groups 1-4 did not differ significantly $(p>0.05)$. A similar tendency was observed when analyzing the value of the number of roots in the samples. It was found that in the experimental samples the number of roots exceeded the number of roots in the control sample $(p<0.001)$. The highest median value of the number of roots in group 1 was $5.38(5.0 ; 6.0)$ and in group 2 this was $5.28(5.0 ; 6.0)$. The median shoot length in the nanoselenium group was $13.85 \mathrm{~mm}(0.0 ; 22.0)$.

As a result of the analysis of data on the length of sprouts, the prevalence of this indicator in groups 1, 3, and 4 from groups 2 and 5 was statistically and reliably established. 
The most important indicator for assessing the quality of seeds is germination percentage. Analysis of statistically processed data shows that the maximum median value of the germination percentage parameter was achieved upon stimulation of germination by selenium nanoparticles-65.0\% $(64.0 ; 66.0)$. At the same time, a statistically significant difference $(p<0.001)$ was established for all studied groups according to the criterion of germination percentage.

In general, and by the data obtained, the preparation of selenium nanoparticles stabilized by PVP C15 $(8 \pm 2 \mathrm{kDa})$ and ascorbic acid, synthesized in this work is less toxic than selenous acid. Additionally, by statistical analysis, the toxic dose of nanoselenium is 10 times more than the toxic dose of selenous acid. Hence, selenium nanoparticles can be widely used in agronomy and agriculture to provide plants with selenium, which is necessary for normal growth and development of crops.

Obtained data can be caused by many factors. The effect of selenium nanoparticles stabilized by PVP can inhibit the phytohormones and enzymes of seeds, affect the antioxidant potential, promote the destruction of morphological microstructures, or affect the output of membranes and nutrient channels $[60,61]$. An important role in the differentiation of the structural elements of roots and sprouts is played by the hormone auxin, which affects the processes of cell elongation. It is believed that free (physiologically active) auxin is a signal necessary for vascular differentiation [62]. Since the bound hormone is not involved in the differentiation of blood vessels, we assume that the violation of the orientation of structural elements in the experimental samples and the intensification of seed growth occurs as a result of the transformation of auxin from the bound form to the free one. Recently, it has been widely believed that auxin in combination with active oxygen forms are the main regulators of plant development under various stresses $[63,64]$. The concentration of auxin may decrease due to a reduction in the biosynthesis of the hormone with an increase in the content of reactive oxygen species, conjugation of the hormone, or due to its direct oxidation when oxidative stress occurs.

Thus, considering the results obtained in the framework of the study, a necessary step for further research is the histological and biochemical study of barley seeds treated with nanosized selenium. Scientific work in this direction will make it possible to determine the mechanisms of the influence of nanosized selenium on biochemical, morphological, and physiological processes occurring during seed germination and crop growth. Additionally, the study of the effect of selenium nanoparticles size on the morphological and functional properties of seeds is of great scientific interest. This will expand the knowledge about the fundamental aspects of the application of non-metal nanoparticles in sowing agricultural engineering.

\section{Conclusions}

A study of the effect of selenium nanoparticles on Hordeum vulgare L. seeds' germination parameters was carried out. It was showed that there is a positive effect of Se nanoparticles on the length of shoots, roots, and the germination percentage. The highest seed germination percentage was recorded in the sample treated with the preparation of selenium nanoparticles at a concentration of $4.65 \mu \mathrm{g} / \mathrm{mL}$.

According to the results, selenium nanoparticles can be used as a source of the essential microelement selenium for the seeds. Preparation of selenium nanoparticles in this study has less toxicity than the ionic forms of selenium, so it can be used to replenish selenium in a germinating seed and restore biochemical processes with its participation. In connection with the positive results of this study, it can be argued that this scientific direction is promising. Therefore, an urgent task is to study the effect of selenium nanoparticle preparations stabilized by other stabilizers, as well as to study the effect of selenium nanoparticles on the germination parameters of other popular agricultural crops, such as maize, rice, and soybeans. We aim to perform these studies in the near future.

Author Contributions: A.A.N., A.V.K. and S.A.S.; methodology, A.A.N. and A.A.B.; software, S.A.I.; validation, A.A.G. and V.V.R.; formal analysis, A.A.K.; investigation, D.G.M.; resources, S.A.S., A.V.S. 
and A.A.B.; data curation, A.V.B., S.A.S. and A.B.G.; writing-original draft preparation, A.V.S. and S.A.S.; writing-review and editing, D.G.M. and A.B.G.; visualization, A.V.K. and S.A.I.; supervision, V.V.R.; project administration, S.A.I. and S.A.S.; funding acquisition. All authors have read and agreed to the published version of the manuscript.

Funding: This research received no external funding.

Institutional Review Board Statement: Not applicable.

Informed Consent Statement: Not applicable.

Data Availability Statement: Not applicable.

Acknowledgments: The studies were carried out using the equipment of the Shared Use Center of North-Caucasus Federal University.

Conflicts of Interest: The authors declare no conflict of interest.

\section{References}

1. Rabiul Awual, M.; Munjur Hasan, M.; Ihara, T.; Yaita, T. Mesoporous silica based novel conjugate adsorbent for efficient selenium(IV) detection and removal from water. Microporous Mesoporous Mater. 2014, 197, 331-338. [CrossRef]

2. Awual, M.R. Solid phase sensitive palladium(II) ions detection and recovery using ligand based efficient conjugate nanomaterials. Chem. Eng. J. 2016, 300, 264-272. [CrossRef]

3. Awual, M.R. Novel nanocomposite materials for efficient and selective mercury ions capturing from wastewater. Chem. Eng. J. 2017, 307, 456-465. [CrossRef]

4. Blinov, A.V.; Siddiqui, S.A.; Nagdalian, A.A.; Blinova, A.A.; Gvozdenko, A.A.; Raffa, V.V.; Oboturova, N.P.; Golik, A.B.; Maglakelidze, D.G.; Ibrahim, S.A. Investigation of the influence of Zinc-containing compounds on the components of the colloidal phase of milk. Arab. J. Chem. 2021, 14, 103229. [CrossRef]

5. Awual, M.R. Ring size dependent crown ether based mesoporous adsorbent for high cesium adsorption from wastewater. Chem. Eng. J. 2016, 303, 539-546. [CrossRef]

6. Awual, M.R. Assessing of lead(III) capturing from contaminated wastewater using ligand doped conjugate adsorbent. Chem. Eng. J. 2016, 289, 65-73. [CrossRef]

7. Awual, M.R. A novel facial composite adsorbent for enhanced copper(II) detection and removal from wastewater. Chem. Eng. J. 2015, 266, 368-375. [CrossRef]

8. Awual, M.R.; Hasan, M.M.; Khaleque, M.A. Efficient selenium(IV) detection and removal from water by tailor-made novel conjugate adsorbent. Sens. Actuators B Chem. 2015, 209, 194-202. [CrossRef]

9. Awual, M.R.; Yaita, T.; Suzuki, S.; Shiwaku, H. Ultimate selenium(IV) monitoring and removal from water using a new class of organic ligand based composite adsorbent. J. Hazard. Mater. 2015, 291, 111-119. [CrossRef] [PubMed]

10. Abdel-Hamid, M.I.; Skulberg, O.M. Effect of selenium on the growth of some selected green and blue-green algae. Lakes Reserv. Sci. Policy Manag. Sustain. Use 1995, 1, 205-211. [CrossRef]

11. Abdelhameed, R.M.; Darwesh, O.M.; Rocha, J.; Silva, A.M.S. IRMOF-3 biological activity enhancement by post-synthetic modification. Eur. J. Inorg. Chem. 2019, 2019, 1243-1249. [CrossRef]

12. Cheboi, P.K.; Siddiqui, S.A.; Onyando, J.; Kiptum, C.K.; Heinz, V. Effect of ploughing techniques on water use and yield of rice in maugo small-holder irrigation scheme, Kenya. AgriEngineering 2021, 3, 110-117. [CrossRef]

13. Emam, H.E.; Darwesh, O.M.; Abdelhameed, R.M. In-growth metal organic framework/synthetic hybrids as antimicrobial fabrics and its toxicity. Colloids Surf. B Biointerfaces 2018, 165, 219-228. [CrossRef] [PubMed]

14. El-Baz, F.K.; Mahmoud, K.; El-Senousy, W.M.; Darwesh, O.M.; ElGohary, A.E. Antiviral - antimicrobial and schistosomicidal activities of Eucalyptus camaldulensis essential oils. Int. J. Pharm. Sci. Rev. Res. 2015, 31, 262-268.

15. Jiang, C.; Zu, C.; Lu, D.; Zheng, Q.; Shen, J.; Wang, H.; Li, D. Effect of exogenous selenium supply on photosynthesis, Na+ accumulation and antioxidative capacity of maize (Zea Mays L.) under salinity stress. Sci. Rep. 2017, 7, 42039. [CrossRef]

16. Jiang, C.; Zu, C.; Shen, J.; Shao, F.; Li, T. Effects of Selenium on the growth and photosynthetic characteristics of flue-cured tobacco (Nicotiana Tabacum L.). Acta Soc. Bot. Pol. 2015, 84, 71-77. [CrossRef]

17. Barabanov, P.V.; Gerasimov, A.V.; Blinov, A.V.; Kravtsov, A.A.; Kravtsov, V.A. Influence of nanosilver on the efficiency of pisum sativum crops germination. Ecotoxicol. Environ. Saf. 2018, 147, 715-719. [CrossRef]

18. El-Ramady, H.R.; Domokos-Szabolcsy, É.; Abdalla, N.A.; Alshaal, T.A.; Shalaby, T.A.; Sztrik, A.; Prokisch, J.; Fári, M. Selenium and nano-selenium in agroecosystems. Environ. Chem. Lett. 2014, 12, 495-510. [CrossRef]

19. Krishnaraj, C.; Jagan, E.G.; Ramachandran, R.; Abirami, S.M.; Mohan, N.; Kalaichelvan, P.T. Effect of biologically synthesized silver nanoparticles on bacopa monnieri (Linn.) wettst. plant growth metabolism. Process Biochem. 2012, 47, 651-658. [CrossRef]

20. Gubbins, E.J.; Batty, L.C.; Lead, J.R. Phytotoxicity of silver nanoparticles to Lemna minor L. Environ. Pollut. 2011, 159, 1551-1559. [CrossRef]

21. Lee, W.-M.; Kwak, J.I.; An, Y.-J. Effect of silver nanoparticles in crop plants phaseolus radiatus and sorghum bicolor: Media effect on phytotoxicity. Chemosphere 2012, 86, 491-499. [CrossRef] 
22. Mirzajani, F.; Askari, H.; Hamzelou, S.; Farzaneh, M.; Ghassempour, A. Effect of silver nanoparticles on Oryza sativa L. and its rhizosphere bacteria. Ecotoxicol. Environ. Saf. 2013, 88, 48-54. [CrossRef]

23. Jiang, H.-S.; Qiu, X.-N.; Li, G.-B.; Li, W.; Yin, L.-Y. Silver nanoparticles induced accumulation of reactive oxygen species and alteration of antioxidant systems in the aquatic plant spirodela polyrhiza. Environ. Toxicol. Chem. 2014, 33, 1398-1405. [CrossRef]

24. Musante, C.; White, J.C. Toxicity of silver and copper to cucurbita pepo: Differential effects of nano and bulk-size particles. Environ. Toxicol. 2012, 27, 510-517. [CrossRef]

25. Siddiqui, S.A.; Ahmad, A.; Siddiqui, A.A.; Chaturvedi, P. Stability Analysis of a Cantilever Structure using ANSYS and MATLAB. In Proceedings of the 2021 2nd International Conference on Intelligent Engineering and Management (ICIEM), London, UK, 28-30 April 2021; pp. 7-12. Available online: https:/ / ieeexplore.ieee.org/document/9445357 (accessed on 12 March 2021).

26. Ayivi, R.; Ibrahim, S.A.; Colleran, H.; Silva, R.; Williams, L.; Galanakis, C.; Fidan, H.; Tomovska, J.; Siddiqui, S.A. COVID-19: Human immune response and the influence of food ingredients and active compounds. Bioact. Compd. Health Dis. 2021, 4, 100-148.

27. Turakainen, M.; Hartikainen, H.; Seppänen, M.M. Effects of selenium treatments on potato (Solanum tuberosum L.) growth and concentrations of soluble sugars and starch. J. Agric. Food Chem. 2004, 52, 5378-5382. [CrossRef]

28. El-Ramady, H.; Faizy, S.E.D.; Abdalla, N.; Taha, H.; Domokos-Szabolcsy, É.; Fari, M.; Brevik, E.C. Selenium and nano-selenium biofortification for human health: Opportunities and challenges. Soil Syst. 2020, 4, 57. [CrossRef]

29. Nagdalian, A.A.; Rzhepakovsky, I.V.; Siddiqui, S.A.; Piskov, S.I.; Oboturova, N.P.; Timchenko, L.D.; Lodygin, A.D.; Blinov, A.V.; Ibrahim, S.A. Analysis of the content of mechanically separated poultry meat in sausage using computing microtomography. J. Food Compos. Anal. 2021, 100, 103918. [CrossRef]

30. Romero, I.; de Francisco, P.; Gutiérrez, J.C.; Martín-González, A. Selenium Cytotoxicity in Tetrahymena thermophila: New clues about its biological effects and cellular resistance mechanisms. Sci. Total Environ. 2019, 671, 850-865. [CrossRef]

31. Oraghi Ardebili, Z.; Ardebili, N.; Jalili, S.; Safiallah, S. The modified qualities of Basil plants by selenium and/or ascorbic acid. Turk. J. Bot. 2015, 39, 401-407. [CrossRef]

32. Velez, M.E.V.; da Luz, J.M.R.; da Silva, M.d.C.S.; Cardoso, W.S.; de Souza Lopes, L.; Vieira, N.A.; Kasuya, M.C.M. Production of bioactive compounds by the mycelial growth of pleurotus djamor in whey powder enriched with selenium. LWT 2019, 114, 108376. [CrossRef]

33. Zimmerman, T.; Siddiqui, S.A.; Bischoff, W.; Ibrahim, S.A. Tackling airborne virus threats in the food industry: A proactive approach. Int. J. Environ. Res. Public Health 2021, 18, 4335. [CrossRef]

34. Lyons, G.H.; Genc, Y.; Soole, K.; Stangoulis, J.C.R.; Liu, F.; Graham, R.D. Selenium increases seed production in brassica. Plant Soil 2009, 318, 73-80. [CrossRef]

35. Hussein, H.-A.A.; Darwesh, O.M.; Mekki, B.B. Environmentally friendly nano-selenium to improve antioxidant system and growth of groundnut cultivars under sandy soil conditions. Biocatal. Agric. Biotechnol. 2019, 18, 101080. [CrossRef]

36. Bao, P.; Li, G.-X.; He, Y.-Q.; Ren, H.-Y. Selenium nanovirus and its cytotoxicity in selenite-exposed higher living organisms. Biochem. Biophys. Rep. 2020, 21, 100733. [CrossRef]

37. Mangiapane, E.; Pessione, A.P. Selenium and selenoproteins: An overview on different biological systems. Curr. Protein Pept. Sci. 2014, 598-607. [CrossRef]

38. Gudkov, S.V.; Shafeev, G.A.; Glinushkin, A.P.; Shkirin, A.V.; Barmina, E.V.; Rakov, I.I.; Simakin, A.V.; Kislov, A.V.; Astashev, M.E.; Vodeneev, V.A.; et al. Production and use of selenium nanoparticles as fertilizers. ACS Omega 2020, 5, 17767-17774. [CrossRef]

39. Hawrylak-Nowak, B. Effect of selenium on selected macronutrients in maize plants. J. Elem. 2008, 13, 513-519.

40. Bennett, W.N. Assessment of selenium toxicity in algae using turbidostat culture. Water Res. 1988, 22, 939-942. [CrossRef]

41. Hussain, B.; Lin, Q.; Hamid, Y.; Sanaullah, M.; Di, L.; Hashmi, M.L.u.R.; Khan, M.B.; He, Z.; Yang, X. Foliage application of selenium and silicon nanoparticles alleviates $\mathrm{Cd}$ and $\mathrm{Pb}$ toxicity in rice (Oryza sativa L.). Sci. Total Environ. 2020, $712,136497$. [CrossRef]

42. Kong, L.; Wang, M.; Bi, D. Selenium modulates the activities of antioxidant enzymes, osmotic homeostasis and promotes the growth of sorrel seedlings under salt stress. Plant Growth Regul. 2005, 45, 155-163. [CrossRef]

43. Lobanov, A.V.; Hatfield, D.L.; Gladyshev, V.N. Eukaryotic selenoproteins and selenoproteomes. Biochim. Biophys. Acta Gen. Subj. 2009, 1790, 1424-1428. [CrossRef] [PubMed]

44. Dumore, N.S.; Mukhopadhyay, M. Antioxidant properties of aqueous selenium nanoparticles (ASeNPs) and its catalysts activity for 1, 1-Diphenyl-2-Picrylhydrazyl (DPPH) reduction. J. Mol. Struct. 2020, 1205, 127637. [CrossRef]

45. Khoei, N.S.; Lampis, S.; Zonaro, E.; Yrjälä, K.; Bernardi, P.; Vallini, G. Insights into selenite reduction and biogenesis of elemental selenium nanoparticles by two environmental isolates of Burkholderia fungorum. New Biotechnol. 2017, 34, 1-11. [CrossRef]

46. Tugarova, A.V.; Mamchenkova, P.V.; Dyatlova, Y.A.; Kamnev, A.A. FTIR and Raman spectroscopic studies of selenium nanoparticles synthesised by the bacterium azospirillum thiophilum. Spectrochim. Acta Part A Mol. Biomol. Spectrosc. 2018, 192, 458-463. [CrossRef]

47. Afsheen, S.; Naseer, H.; Iqbal, T.; Abrar, M.; Bashir, A.; Ijaz, M. Synthesis and characterization of metal sulphide nanoparticles to investigate the effect of nanoparticles on germination of soybean and wheat seeds. Mater. Chem. Phys. 2020, $252,123216$. [CrossRef]

48. Awasthi, A.; Bansal, S.; Jangir, L.K.; Awasthi, G.; Awasthi, K.K.; Awasthi, K. Effect of ZnO nanoparticles on germination of triticum aestivum seeds. Macromol. Symp. 2017, 376, 1700043. [CrossRef] 
49. Savithramma, N.; Ankanna, S.; Bhumi, G. Effect of nanoparticles on seed germination and seedling growth of Boswellia ovalifoliolata-An endemic and endangered medicinal tree taxon. Biology 2012, 2, 61-68.

50. Siddiqui, S.A.; Ahmad, A. Implementation of thin-walled approximation to evaluate properties of complex steel sections using C++. SN Comput. Sci. 2020, 1, 342. [CrossRef]

51. Siddiqui, S.A.; Ahmad, A. Implementation of Newton's algorithm using FORTRAN. SN Comput. Sci. 2020, 1, 348. [CrossRef]

52. Goldan, A.H.; Li, C.; Pennycook, S.J.; Schneider, J.; Blom, A.; Zhao, W. Molecular structure of vapor-deposited amorphous selenium. J. Appl. Phys. 2016, 120, 135101. [CrossRef]

53. Siddiqui, S.A.; Ahmad, A. Dynamic analysis of an observation tower subjected to wind loads using ANSYS. In Proceedings of the 2021 2nd International Conference on Computation, Automation and Knowledge Management (ICCAKM), Dubai, United Arab Emirates, 19-21 January 2021; Available online: https://ieeexplore.ieee.org/abstract/document/9357728 (accessed on 10 February 2021).

54. Matai, I.; Pandey, S.K.; Garg, D.; Rani, K.; Sachdev, A. Phytogreen synthesis of multifunctional nano selenium with antibacterial and antioxidant implications. Nano Express 2020, 1, 10031. [CrossRef]

55. Bodnar, M.; Konieczka, P.; Namiesnik, J. The properties, functions, and use of selenium compounds in living organisms. J. Environ. Sci. Health Part C 2012, 30, 225-252. [CrossRef]

56. Kiełczykowska, M.; Kocot, J.; Paździor, M.; Musik, I. Selenium-a fascinating antioxidant of protective properties. Adv. Clin. Exp. Med. 2018, 27, 245-255. [CrossRef] [PubMed]

57. Pilon-Smits, E.A.H. Selenium in Plants BT-Progress in Botany; Lüttge, U., Beyschlag, W., Eds.; Springer International Publishing: Cham, Switzerland, 2015; Volume 76, pp. 93-107. [CrossRef]

58. Hadrup, N.; Ravn-Haren, G. Acute human toxicity and mortality after selenium ingestion: A review. J. Trace Elem. Med. Biol. 2020, 58, 126435. [CrossRef]

59. Kury, G.; Rev-Kury, L.H.; Crosby, R.J. The effect of selenous acid on the hematopoietic system of chicken embryos. Toxicol. Appl. Pharmacol. 1967, 11, 449-458. [CrossRef]

60. Li, Y.; Zhu, N.; Liang, X.; Zheng, L.; Zhang, C.; Li, Y.-F.; Zhang, Z.; Gao, Y.; Zhao, J. A comparative study on the accumulation, translocation and transformation of selenite, selenate, and SeNPs in a hydroponic-plant system. Ecotoxicol. Environ. Saf. 2020, 189, 109955. [CrossRef]

61. Hao, Y.; Yu, F.; Lv, R.; Ma, C.; Zhang, Z.; Rui, Y.; Liu, L.; Cao, W.; Xing, B. Carbon nanotubes filled with different ferromagnetic alloys affect the growth and development of rice seedlings by changing the C:N ratio and plant hormones concentrations. PLoS ONE 2016, 11, e0157264. [CrossRef] [PubMed]

62. Van Nhan, L.; Ma, C.; Rui, Y.; Cao, W.; Deng, Y.; Liu, L.; Xing, B. The effects of $\mathrm{Fe}_{2} \mathrm{O}_{3}$ nanoparticles on physiology and insecticide activity in non-transgenic and Bt-transgenic Cotton. Front. Plant Sci. 2016, 6, 1263. [CrossRef] [PubMed]

63. Hao, Y.; Zhang, Z.; Rui, Y.-K.; Ren, J.-Y.; Hou, T.-Q.; Wu, S.-J.; Rui, M.-M.; Jiang, F.-P.; Liu, L.-M. Effect of Different Nanoparticles on Seed Germination and Seedling Growth in Rice. In Proceedings of the 2nd Annual International Conference on Advanced Material Engineering (AME 2016), Wuhan, China, 15-17 April 2016; Volume 6, pp. 166-173. [CrossRef]

64. Mehdizadeh, M.; Mushtaq, W.; Anusha Siddiqui, S.; Ayadi, S.; Kaur, P.; Yeboah, S.; Mazraedoost, S.; AL-Taey, D.K.A.; Tampubolon, K. Herbicide Residues in Agroecosystems: Fate, Detection, and Effect on Non-Target Plants. Rev. Agric. Sci. 2021, 9, $157-167$. [CrossRef] 